\title{
Calf Health and Management Practices in Small Holder Dairy Farms in and Around Wolaita Sodo Town, Southern Ethiopia
}

\author{
Tekalign Woldehana and Tesfalem Tola \\ Univeresity of Gondar, Faculity of Veterinary Medicine, Gondar, Ethiopia, P.O.B.196
}

\begin{abstract}
A questionnaire, observational (by farm visit) and clinical surveys were conducted to assess management, constraint and major health problems associated with calves found in smallholder dairy farms in and around Wolyita Sodo, Southern Ethiopia. Considerable proportions (47.15\%) of the farmers were female. $54.4 \%$ and $32.8 \%$ of the dairy farm owners had more than ten and five years of dairy farming experience respectively. In relation with calf management, $78.6 \%$ of the owners kept their calves in the same shed as adult animals; more over in $90 \%$ of the cases calving location was found to be in the same barn where other animals are kept, on top of this the housesit were poorly constructed in many instances. The majority (77.1\%) of the farmers already knew the importance of colostrum feeding, however $15.7 \%$ of the owners do not know the appropriate time to feed colostrum to their calves. The majority $(75.7 \%)$ of the farmers reported providing of supplement feeds for their calves. The following calf health problems were reported by the dairy farm owners when they were asked to list the major disease type they had observed before: still birth, respiratory problem (pneumonia), diarrhoea, loss of weight and constipation, with report proportions of $18.6,17.1 \%, 11.4 \%, 10 \%, 8.6 \%$ respectively. Up on clinical examination, out of the 141 calves examined 44 (31.21\%) of them showed clinical sign (health problem), with an overall morbidity (prevalence) of $13.48 \%, 12.17 \%, 9.22 \%$ and $0.7 \%$ for pneumonia, diarrhoea, eye infection and abdominal distension respectively, in addition $17.02 \%$ of the examined calves showed a poor body condition. However the body condition of the examined calves was found to have some association with the overall occurrence of any disease problem $\left(\chi^{2}=9.68, \mathrm{df}=2, \mathrm{P}=0.008\right)$. In conclusion, the management and health problems found in calves in this study were could affect the productivity of the dairy farms, therefore effort should be initiated to improve the calves health.
\end{abstract}

Keywords: Calf, Health problem, Management, Smallholder dairy farms.

DOI: $10.7176 / \mathrm{JHMN} / 96-01$

Publication date: December $31^{\text {st }} 2021$

\section{INTRODUCTION}

In Ethiopia, market oriented smallholder dairy farms(MOSH) is an important and emerging business. The system is characterized by the use crossbreed dairy cows, stall feeding proximity to urban centres (Azage et al., 2000). The sector is contributing immensely towards filling in the large demand-supply gap for milk and milk products in urban centers, where consumption of milk and milk products is remarkably high (Azage and Alemu 1998). The urban and peri-urban dairy production system has tremendous potential for development and could play a significant role in minimizing the acute shortage of dairy products in urban centers of Ethiopia.

The major constraints for the development of peri-urban dairying and the development of livestock industry in general have been summarized as policy, socioeconomic, institutional, technical and technological (Tegegne and Gebrewold, 1998). Animal diseases and management problems are among the technical and technological constraints for the peri-urban and urban dairy production systems (Tegegne and Gebrewold, 1998; Belihu, 2002).

Among the important health problems identified by different researchers' reproductive inefficiency, young mortality and some cattle diseases like mastitis, lameness, pneumonia, calf scour and ketosis are the major health problems in intensive dairy production (ILCA, 1994, Wudu et al.,2008). In developed countries, an increase of $10-40 \%$ for mastitis, $10-20 \%$ for calf mortality and $5-15 \%$ for lameness was observed to be associated with intensification of dairy production (ILCA, 1994).

Similarly, a three-fold increase in mastitis, calf mortality and lameness was observed from less intensive to more intensive groups in dairy production systems of Addis Ababa milk shed (ILRI, 1996). Within the dairy production system rearing calf is a key component, this because, the successful raising of healthy calves that grow optimally and attain either reproductive life or market weight age is vital to the sustenance of the dairy or beef herds . High calf mortality can severely affect the pool of available replacement heifers especially in the dairy enterprises. The most significant loss in the dairy or beef enterprises is associated with calf mortality (Radostitis, 1994 ). Various studies have been conducted in the past from many parts of the world using both retrospective and prospective data sources to document the major causes of calf mortality (Gitau et al. 1994: Gitau et al. 1999; Wudu et al. 2008).

The promotion of commercial dairy production around Wolyita Sodo was going on since 1967 (Ninprat, 2006) and attempts were also made to improve dairy production of smallholder farmers in the area through a number of agricultural development projects. Prominent among these are Swedish International Development 
Agency. In relation to calf management and health problems there is no documented information for the smallholder dairy farms found in and around Wolayita Sodo.

The objective of this study are:-

* Initiated to assess the management practices, constraints and major health problems of calves in and around Wolyita Sodo.

\section{LITERATURE REVIEW}

\subsection{The Calf}

Calf refers to the age group of young cattle from birth to six or nine month of age (West, 1995). Elsewhere it was defined as cattle up to six month of age after which in natural circumstances, it might be expected to be selfsufficient (Webster, 1984). The term calf in less intensive system of production, may generally include cattle older than the age indicated in the above definitions. The proportion of calves weaned before six months of age increases from less intensive to more intensive systems of production (ILRI, 1996).

Calves have some special features in their body system that have relevance in disease occurrence and accordingly require special attention in management. Those that have particular importance are the poorly developed defense mechanism and a dynamic digestive system that has to evolve from milk digestion to a solid feed digestion. These make calves particularly susceptible to disease. A newborn calf has poorly developed defense mechanism. The normal flora is not well established and unlike to newborn of primates, they are born with no circulating antibodies to combat infection (Bath et al., 1985).

Yet the calf must survive in highly contaminated environment. In the digestive system of newborn calves, there are certain alterations. There is delay in acid secretion from stomach and in the development of pancreatic function; thus acid and trypsin digestion of protein is not started. The newborn calves have also specialized intestinal epithelium capable of engulfing soluble protein, which will disappear within 24 hours after birth (Cunningham, 1992).

All these help calves to absorb intact immunoglobulin from colostrums. Pre-weaned calves have physiologically monogastric type stomach. The liquid feed flows through the closed esophageal groove directly into the abomasum thus bypassing the fore-stomach. For the newborn calves, it is most important that closure occur prior to feeding, so that the liquid feed will be prevented from entering the rumen and causing digestive disturbance (Blowey, 1990). Other chemical and physical components of digestive system develop with age as the calf starts feeding on different feeds (Heinrichs and Radostits, 2001).

\subsection{Colostrum and its Role in Neonatal Calf Management}

The less developed immune system and lack of previous exposure to infection make newborn animals susceptible to infectious diseases. To compensate this, neonates possess mechanism to acquire maternally derived immune factors. The mode of passive transfer in neonates varies with the type of placentation and in the case of neonatal calves; it is based on an immediate postpartum ingestion of antibody rich colostrum (Tizard, 1995). Colostrum, the first milk produced by the cow at calving, has two important properties: source of immunity and highly nutritious balanced diet for newborn calves. The immunity obtained from colostrum is composed of maternal immunoglobulin, immune active substances and active immune responsive cells (Garry et al., 1993).

Providing the newborn calves with sufficient quantity and good quality of colostrum at the right time is the most important aspect of calf management. For maximum protection against infection, newborn calves should receive colostrum amounting up to $6 \%$ of their body weight within six hours after birth. The highest absorption of immunoglobulin occurs during this period and by 24 hours most of absorption capability is lost (Bath et al., 1985). Colostrum feeding should continue in the second and third day after birth. The immunoglobulin during this period, though not absorbed, will provide some local protective action against bacteria and other organism in the digestive tract. Many studies have demonstrated the importance of high level of serum immunoglobulin in reducing risk of morbidity and mortality in calves (Bakheit, 1981; Hancock, 1985; White and Andrew, 1986; Virtala et al., 1999; Amoki, 2001).

\subsection{Economic importance}

Calf hood diseases have a major impact on the economic viability of cattle operations, due to the direct costs of calf losses and treatment and the long term effects on performance (Donovan, 1998).

Calf death also causes a loss of genetic material for herd improvement and decreases the number of dairy heifers available for herd replacement and expansion. Economic losses resulting from calf hood mortality and morbidity can be easily recognized, but the effect of morbidity on future health and performance, which may constitute a loss of even greater importance, is difficult to estimate. A dairy farm management system should employ a strategy that will reduce calf mortality and improve calf performance by controlling diseases. In a good management practices, annual mortality of calves under one months of age can be reduced to below $3-5 \%$ and 
first calving age at around 24 months (Heinrichs and Radostits, 2001).

Furthermore, the prevalence of gastrointestinal parasites, the genera of (Hailu,et al ., 2011) helminth parasites involved, species and the severity of infection also vary considerably depending on local environmental conditions such ashumidity, temperature, rainfall, vegetation and management practices (Barger, 1999; Kassai, 1999).

\subsection{Determinant of calf health problem}

1.4.1. Breed of calf

Differences in susceptibility of calves to diseases are often observed among different breeds. Taurine breeds and their crosses are generally more susceptible to diseases in tropical climates. In one study in Ethiopian highlands, a higher mortality rate $(62 \%)$ was recorded in $87 \%$ Friesian $\mathrm{x}$ Boran crosses than $75 \%$ Friesian $\mathrm{x}$ Boran crosses 32\% (Gryseels and de Boodet, 1986; Hailemariam et al. (1993a) also found higher calf mortality in exotic breeds than locals. Mortality and morbidity also differ among calves of temperate dairy breeds (Olsson et al., 1993; Agerholm et al., 1993).

1.4.2. Age of the Calf

The age of the calf is the most important factor affecting morbidity and mortality. Approximately $75 \%$ of the mortality, in dairy animals under one year of age, occurs in the first month of their life (Heinrichs and Radostits, 2001).

In a three-month study on Swedish dairy farms, $70 \%$ of the mortality occurred in the first month of the calves' age and the first week of age is with higher risk of dying than any other time there after (Waltner-Toews et al., 1986c; Olsson et al., 1993). Similarly, Virtala et al., (1996b) in their 3 months study reported the peak occurrence of crude mortality and diarrhea at the second week of life. In a study on smallholder dairying in Debre Zeit, $15 \%$ of the mortality rate was reported in the first month as compared to $8 \%$ mortality rate in 1 to 3 month of life (Gryseels and de Boodet, 1986). What all these studies showed was that young age is the critical age for calves and producers need special attention for young calves.

1.4.3. The weaning period

The median age at weaning was 8 weeks. Almost half the herds (46\%) used the 'age' of the calf as a criterion for time of weaning. In $18 \%$ of the herds 'concentrate consumption' was used as criterion to decide when to wean a calf; these farmers aimed that their calves had median concentrate consumption at weaning of $1 \mathrm{~kg}$. Seven percent of the herds used the calf's 'body weight' as criterion; in those herds the farmers aimed at a median weight at weaning of $70 \mathrm{~kg}$.

Combinations of these alternatives were used to determine the appropriate weaning time in $29 \%$ of the herds. In $32 \%$ of the herds the weaning procedure was to dilute the milk with successively increasing volumes of water during, as a median, 7 days. In $21 \%$ of the herds the weaning procedure was 'simply to stop giving milk'. Another $21 \%$ gave their calves just one meal of milk per day for, as a median, 5 days .before the total removal of milk. In $19 \%$ of the herds the calves received a smaller volume of milk per meal during, as a median, 7 days and the remaining herds used (Warnick,1977).

\subsection{Calf management}

1.5.1. Farm Personnel

There is a marked influence of who feeds and cares for calves on calf's health. Fewer death losses were observed on farms where the owner managed the calves than on farms where employees performed the duties (Britney et al., 1984). This suggests that owners might be motivated sufficiently to provide the care necessary to insure high survival. Similarly, low calf mortality was seen in herds owned by older and more experienced managers (Heinrichs and Radostits, 2001).

\subsubsection{Feeding Management}

Feed and feeding methods are important risk factors in morbidity and mortality of dairy calves. Feeding starts with colostrum soon after birth and involves feeding liquid feeds to pre-weaned calves and solid feeds to weaned calves (Bath et al., 1985).

\subsubsection{Colostrum Feeding}

Ingestion and absorption of enough quantity and quality of colostrum is a critical determinant for the health and survival of neonatal calves. Calves, which do not received adequate colostrum are shown to have higher overall death rate, specially from septicemia and joint ill and are more likely to develop scouring and pneumonia, even at two to three months old (Blowey,1990). Wittum et al., (1994) found that calves with inadequate blood colostral immunoglobulin concentration in 24 hours of birth were at greater risk of neonatal morbidity and mortality, preweaning morbidity and morbidity and respiratory problems while in feedlot. Several reports have shown the importance of colostrum in relation to the risk of calf mortality and morbidity (Edwards et al., 1982; Waltner-Toews et al., 1986d; Aldridge et al., 1992 ).

The passive transfer of colostral immunity from dam to the neonatal calf is believed to be affected by 
several factors including age at first feeding, volume and concentration of the immunoglobulin in the colostrum fed, birth weight, method of feeding, seasonal influence, stress, use of colostral supplements, etc.(Aldridge et al., 1992; Drewry et al., 1999).

Time between birth and the first feeding is the prime factor for the failure of passive transfer of colostral immunity. Studies showed that calf mortality is significantly higher in calves that got colostrum late after birth than those that got colostrum soon after birth (Bruning-Fann and Kaneene, 1992; Wells et al., 1996). In one study, it was found that each hour of delay within the range of 1 to 12 hours after birth increased the risk of illness by $10 \%$ (Olsson et al., 1993).

The concentration of immunoglobulin is also important factor in colostral immunity. This is again affected by the dry period of the dam and genetic line of cattle. In a study by Besser et al. (1991) it was reported that a minimum of 40 days and a maximum of 90 dry days resulted in best quality colostrum and dry cows that leaked milk prior to parturition have lost the best colostrum.

Generally, some cattle are prone to low immunoglobulin level in their colostrum. For example, beef cattle breeds have higher immunoglobulin concentration than Holsteins and among dairy breeds, it is higher in Holstein than in Guerency (Rebhun et al, 1995; Tyler et al., 1999). Although colostrum from first lactating heifers usually was thought to be insufficient, some studies showed that it is adequate (Tayler et al, 1999).

The volume of colostrum and method of feeding are important factors to achieve the desired level of colostral immunity (Besser et al., 1991). According to this study the method of feeding was more important factor for failure of passive immunity in calves than other management factors like the use of previously frozen colostrum and from cows with long lactating interval. Again in the same study, it was observed that failure to passive transfer immunity was less frequent in dairies that used artificial feeding (nipple bottle-feeding and tube feeding), than in dairies that allow calves to suckle. In the later case, the prevalence of failure to passive transfer was greater than $50 \%$ even among calves nursed by cows with above average colostral IgG concentration. Similarly, another study indicated improvement of the passive transfer when suckling was supplemented with bottle feeding (Bringole and Stott, 1980). This is suggested to be due to inability of calves to ingest enough volume of colostrum by suckling.

Passive immunity transfer in calves is also influenced by season. A study showed that the level of colostral immunoglobulin in calves' serum was higher during summer than winter (Gay et al., 1983). This seasonal variation could be probably due to variations in immunoglobulin concentration in colostrum or ability to absorb immunoglobulin from colostrum in different seasons. There is also evidence that mastitis during dry period of cows decreases the concentration of IgG, particularly IgG1 in the colostrum of the next lactation (Komine et al., 2000).

1.5.4. Feeding after colostrum

Pre-weaned calves in modern dairy herds are fed with milk or milk replacer. The quality of feed and the method of feeding require great care. The feeding method and time of feeding for pre-weaned calves that fail to insure the closure of oesophageal groove, leads the feed to rumen and causes digestive upset (Blowey, 1990). Method of feeding was also associated with some contagious diseases (Wilson et al., 1998). In this study, the proportion of calves infected with ETEC on the farm was positively associated with the use of regular pails for feeding calves (as opposed to nipple bottles or nipples pails).

A transition from liquid pre-weaned feed to solid weaned calf feed is also a critical time in feeding calves. If this is not done carefully, the calf will get dietary stress and be susceptible for different diseases (Blowey, 1990; Cry et al., 1998).

1.5.5. Milk and a milk replacer

the amount of milk to be feed depend on the size of the calf and usually 8 to $10 \%$ of its birth mass, over feed may result in digestive upset and scours. When restricted level of milk are feed or "high dry matter" milk replacer are used ,the calf will get in safisent liquid in its feed for its daily requirement and water must be freely available. Begin milk replacer feeding as soon as colostrums feeding has ended .replacer low in fiber are preferable because this contain the last amount vegetable protein .the most suitable milk replacer consist almost entirely milk by products.(Hill et,al., 2007).

1.5.6. Starter feed

After starter feed to calf each day onset the calve are resaving milk replacer the most component of a good quality starter feed are cereal grain .they provide texture and contain high level of fermentable carbohydrate, provide are daily available energy source the end product of grain digestion stimulate rumen papilla growth .hey $\mathrm{o} n$ the other hand doesn't have major benefit effect on rumen growth .its presences in the diet reduce energy density, takes up space in the digestive tract and tends to increase the time to weaning.hay should be reserved as after weaning feed,when it's important to develop rumen musculature .Research show that starter contain 19$20 \%$ crude protein proved an optimum growth rate (lyimon et., al 2004).

1.5.7. Watering

Fresh clean water is critical for successful rumen development and should be made available as soon as the calf 
begin drinking milk replacer .for rumen development to occur bacterial must be present . Since the calf is born without rumen bacteria, it is must build the bacterial population over time .consumption of water is critical for the this process since bacteria live and grow in water environment water must be feed separate from milk replacer for water to inter the rumen. This is dye to the formation of unique structure called esophageal groove .young dairy calve have higher requirement for water than older animal per unit of body weight .research showed that calve receive free chose water had a127g higher average daily gain camper to calve receiving no additional water (Cunningham,1992).

1.5.8. Housing

On most dairy farms, calves are taken from the maternity area soon after birth and placed in the calf-rearing barn. Calves raised for herd replacement are commonly maintained in facilities that range from total confinement to open pastures. The greater the confinement, the more the calves environment is under the control of the producer and the less calves are able to make behavioural response to that environment. Morbidity and mortality rates are usually higher in calves housed indoors than outdoors. The increased illness and mortality in calves that are reared indoors is often attributed to a combination of inadequate control of thermal environment, poor air quality, undesirable relative humidity, inadequate exchange of air and poor sanitation (Blowey, 1990).

Different calf housing types have been associated with different rates of calf morbidity and mortality. In one study, producers who housed in calf hutch experienced lower calf mortality than producers who used any other type of housing, and housing calves in a group pens significantly increased risk of calf morbidity and mortality (Lance et al., 1992a). Another study by Olsson et al. (1993) also indicated that keeping calves in single pen decreased incidence of enteritis as compared to group pens.

1.5.9. Herd Size

A marked increase in population density commonly results in an increase in the incidence of infectious diseases. Different studies reported significantly lower calf mortality in dairies having small herds than large or medium herd size (Bruning-Fann and Kaneene, 1992). Garber et al. (1994) found higher prevalence of Cryptosporidium associated with larger herd size in dairy farms. Herd size by itself has not a biological effect on the calf health; rather, it may be a measurement of other factors like time available to observe and care for calves. Other possible reason for the apparent association between herd size and calf mortality could be that in case of small herd sizes enough time may elapse between successive births, which will reduce the concentration of infectious agents in the calf-rearing environment.

1.5.10. Season of the Year

Season is important in areas where the climate goes to either extremity. In areas where winter temperature is very cold there will be more mortality of calves that are born in this season (Aiello, 1998). According to review on calf morbidity and mortality by Bruning-Fann and Keneene (1992), calves suffer morbidity and mortality and show less performance during winter than other seasons. This seasonal influence could be due to cold temperature itself or due to long period of housing which may lead to the increase of infection pressure and poor ventilation. In tropical areas high mortality was reported in hot dry season (Hailemariam et al., 1993b) which could arise from shortage of feed in dry season.

\subsection{Major health problem of calf}

1.6.1. Viral disease

The most common viral agents that cause disease in calves are Rotavirus and Corona virus. Rotavirus belongs to the family Reoviridae. There are six groups of the genus Rotavirus. Of these groups, Group A Rotavirus is the most prevalent and clinically important and containing several serotypes of differing virulence (Murphy et al., 1999). Rotavirus has been shown to be the most common cause of scouring in calves during their first week of life (Snodgrass et al., 1982; Reynolds et al., 1986; Hunt, 1993).

Rotavirus is present in all dairy herds but only under certain condition like, poor hygiene and/or a heavy challenge does it cause disease. Rotavirus replicates in the mature absorptive and enzyme producing enterocytes on the villi of small intestine, leading to rupture and sloughing of the enterocytes with release of virus to infect adjacent cells. With virulent strains of rotavirus, the loss of enterocytes exceeds the ability of the intestinal crypts to replace them; hence, the villi height is reduced, with a consequent decrease in intestinal absorptive area and intestinal digestive enzyme activity leading to scouring (Aiello, 1998).

Bovine Coronaviruses belongs to the family of Coronaviridae. They are second to rotavirus as a cause of calf diarrhea (Murphy et al., 1999). It was the predominant pathogen detected from diarrheic calves in one study in Ethiopia (Abraham et al., 1992). It replicates in the epithelium of upper respiratory tract and in the enterocytes of the intestine where it produces similar lesion to rotavirus. It cause diarrhea in young calves of few weeks age. 1.6.2. Bacterial

The most common Bacterial agents that cause disease in calves are salmonella and E. coli. The genus Salmonella contains a single species with more than 2000 serologic variants. Salmonella serotypes especially Salmonella typhimurium and Salmonella dublin and occasionally others cause diarrhea in calves of 2-12 weeks of age. The 
commonest serotype is Salmonella typhimurium. This organism produces enterotoxin but also is invasive and produces change within the intestine. The disease is seen as profuse diarrhea with septicemia and death may occur within 24 hours. Chronic form of the disease is also common, in which the affected calf simply has pasty dung and unthriftness. At the far end of the spectrum, some calves may carry the infection without suffering any adverse effects (Aiello, 1998).

Escherichia coli cause two common diseases of newborn calves. In Coli septicemia the bacteria invade the systemic circulation and internal organs, and enteric collibacillosis the bacterial are localized in the lumen and mucosal surface of the small intestine. The serotypes of E. coli that cause these diseases differ. Each type possesses unique attributes of virulence that differentiate it from each other as well as from non-pathogenic serotypes of E.coli that are normal digestive flora of healthy calves (Acres, 1985).

The types of $E$. coli that cause diarrhea commonly are enterotoxigenic $E$. coli (ETEC). These types of $E$. coli possess two characteristics of virulence that play role in their pathogenicities. These include their ability to produce entertoxins, which stimulate fluid secretion from the intestine and presence of pilli (fimbriae), which allow the bacteria to adhere to epithelial cells of small intestine. E coli serotypes that have the ability to adhere to wall of small intestine of calves possess K99 fimbrial antigen. With their fimbriae they attach to the wall of the calf intestine and produce enterotoxins. These toxins stimulate the calf to produce excessive quantities of intestinal secretions, thus leading to severe diarrhea. ETEC usually interact positively with other pathogens like rotavirus and Cryptosporidium to cause diarrhea in calves (Snodgrass et al., 1982; Runnel et al., 1986). Most of the time ETEC cause diarrhea in calves of less than one week of age (Acres, 1985; Reynolds et al., 1986; Abraham et al., 1992).

1.6.3. Parasitic disease

Parasitic worms that cause disease in calves are trematodes (e.g. Fadsciola, Paramphstomum), Cestodes (e.g. Monezia), Nematodes (e.g. Strongiles, Dictlcaulos ) and protozoa (e.g. Coccidia, Cryptospordism).

The common liver fluke fasciola hepatica is mast important trimatod of domestic ruminant and the most common cause of liver fluke disease in temperate area. The highest infection risk is at the end of grazing season because the snail population increase until autumn and their by more infection larva (mrtasercaria), can be released by the snail on the posture, infection occur by infection of metasercaria contain herbage; heifer are endanger after the first grazing season. Cattle are often affected by the common liver fluke because they are often grazing on the wettest posture of the farm (Menge, 2002 and Loyacan2002).

Paraphistome are distributed worldwide. Infection is acquired by ingestion of the herbage contaminated with infected stage (metasercaria). The adult fluke are generally non pathogenic ( $>80 \%$ of adult cattle are affected in an endemic area). disease occur when mass of immature fluke attack to the intestinal mucosa after excitement, cause distraction and infection, saver diaharia and weakness generally cause by the immature intestinal fluke, may lead to death sever symptom are observed mainly in young stock. (Szmiid,et,al 2000)

The most tape warm monazia bendeni and moniezia expansa are distributed worldwide. M.bendeny more often in cattle monaza expanza in sheep. The life cycle is in direct and include many species of orbited mite (orbited mite) as intermediate host. The mite lives in human rich soil. Cattle are infected by ingestion of infected mite on herbage the infection stage of monazia are cyctocercodes, which can survive up to 2yearsin the mite. Infestation of monazia remains often without clinical sign but pathogenic effect is not clear. The highest infestation risk occurs often turn out on posture on spring. The first grazing season cattle are most susceptible (Marseden and Werren, 1984).

Gastrointestinal stronloids are distributed worldwide .the specie belong to the order of strongleda.In the order the family tricostronglidy with the genera ostretege,cooperiaand heamoncose in the tropical region are most important. The gastrointestinal nematode have direct life cycle without intermediate host. Cattle are infecting by infectious third stage larva on the herbage. First grazing season on calve are most in danger to fall ill dye to infection with gastrointestinal stronglod older cattle have mostly build up natural acquired immunity, the highest infestation risk is in the second season half of the grazing period from mid July to mid September (Nansen, 1988).

The cattle lung warm is distributed worldwide and cause the parasitic bronchitis, which is characterized by sever coughing rapid breathing, desphina and rapid cost of condition (retared growth) sever cause lead to empesima and pneumonia. The life cycle of Dicocoulos viviparse direct without intermediate host 3-4 lung worm generation can occur per grazing period.The cattle are infected by ingestion infectious third stage larva on herbage .The highest infestation risk is given in the season half of the grazing period .In general mostly firs grazing season calve fall ill towards end of summer .Manly in humid and rainy year. Older cattle mostly have build up natural acquired immunity (Taylor, 2000).

Young animal became infected by ingesting sporulated oocyte in contaminated food and water. The parasite usually migrates in to the intestinal mucosa membrane where oocyte is produce which passes out in the feces. Successive infection in young animal may cause the animal to excretion will heavily contaminated kraals and watering place. The multiplication of the parasite in the intestine causes damage to the mucosa membrane. The 
severity of this damage depends on number of oocyte ingested. Clinical sign is usually seen in young animal. Prominent sign of clinical coccidiosis is diarrhea which is same times bloody. Affected animal have poor growth rate, severely affected animal may die (Maingi, 1996).

The prevalence of Eimeria in cattle range between $12-100 \%$ and the execration of oocyte in faces is mostly low. coccidosis which is accompanied by high oocyt excretion per gram of faces $(50,000-500,000)$, can cause bloody diarrhea, loss and death, particularly in management system with restricted area high infection risk is given at infection contaminated places, such as drinker, feeding trough, deep liter, well and cout of skin animal.(Aiello,1998).

Cryptosporidium parvum is coccidian parasite that affect domestic animals and man. It was reported as one of the most common cause of diarrhea in calves (Ongerth and Stibbs, 1989; McDonough et al., 1994; Quilez et al., 1996). The parasite does not invade but adheres to the apical surface of enterocytes in the distal small intestine and the colon. This result in the loss of microvilli, decreased mucosal enzyme activity with villus blunting and fusion (leading to reduced villus absorptive area) and inflammatory changes in the submucosa. The organism is endemic in all cattle herds and as with rotavirus and coronavirus, most calves are at high risk of infection between birth and weaning, and poor ventilation and filthy barn predisposes to infection (Mohammed et al., 1999).

\subsection{Another health problem}

\subsubsection{Calf Diarrhea}

Calf diarrhea is the commonest disease in young calves and is the greatest single cause of death (Gitau et al., 1994; Sivula et al., 1996a; Busato et al., 1997; Heinrichs and Radostits, 2001). It accounts for approximately $75 \%$ of the mortality of dairy calves under three weeks of age (Blowey, 1990). It is also a complex syndrome of great etiological complexity. In addition to the influence of varied environmental, managemental and nutritional factors, the infectious agents capable of causing diarrhea in calves are numerous. The most important causes of diarrhea in calves include enterotoxigenic Esherichia coli, Salmonella, Rotavirus, Coronavirus, Cryptosporidia and Emeria Spp. (Waltner_Toews et al., 1986e; Reynolds et al, 1986; Snodgrass et al., 1986; Abraham et al., 1992).

Failure of passive immunity transfer and overwhelming pathogen exposure are the main precipitating factors for calf diarrhea. Four mechanisms have been demonstrated to be important in occurrence of diarrhea in calves. Hypersecretion of ions and water into the bowl, increased osmotic pressure from maldigestion malabsorption disease caused by damage to enterocytes, increased mucosal permeability due to inflammation, and the last and less important mechanism is alteration of intestinal motility (Hunt, 1993).

1.7.2. Calf Pneumonia (Enzootic Pneumonia)

Although it can affect pre-weaned calves, this is the most common of all the diseases of the weaned calves and causes the highest loss in this age group, both in terms of mortality and reduced growth rates and accounts for about $15 \%$ of calf mortality from birth to 6 month of age (Heinrichs and Radostits, 2001). Calf pneumonia is a multiple etiology syndrome, that is caused by one or more of a whole range of organisms, including bacteria (like Pasteurella multocida, P. haemolytica, Hemophilus somnus, Actinomyces pyogenes), virus (like Respiratory syncytial virus, Parainfulenza virus type 3 etc.) and Mycoplasma (M. bovis, M. dispar) (Sivula et al., 1996a; Virtala et al., 1996a). Environmental factors like inadequate ventilation are extremely important in the occurrence of calf pneumonia. The disease is characterized by clear nasal discharge and raised temperature in early stage and coughing and faster breathing rate later. Some acute outbreaks can occur with fatalities before any significant coughing has been heard (Blowey, 1990).

1.7.3. Navel ill (omphalitis)

Localized inflammation or infection of the contents of the umbilical cord external to the body wall is referred to navel ill (omphalitis). Omphalophlebitis, omphaloarthritis, and urachitis are terms used further describe the extension of inflammation or infection from the external umbilicus to the intra-abdominal segment of the umbilical vein, umbilical arteries, and urachus respectively. The most frequently isolated pathogen from navel ill is Actinomyces pyogens in mixed infection with other bacteria usually E .coli (Kasari, 1993). Survey on the incidence of umbilical infection showed that the age of calves for its occurrence is usually in the first week of life (Virtala et al., 1996b). According to some studies, it is one of the disease conditions which has serious effect on future survival and productivity of calves (Britney et al., 1984).

1.7.4. Sudden death syndrome

Usually in calve 3 to 8 week age; this is caused by closrudiume prifringe bacteria that are found naturally in the soil and in the gut of normal calves. clostrodial organism multiply rapidly under conditions when calves are over feed grain and milk ,producing powerful entrotoxine that damages blood vessel,the braine and ather tissue and cousing sudden death. Same protection may be provided by vassineting dry caw with colostrum type C and D toxiod at approximately 6 weak 3 weak priore to calving. Thus will increase the concentration of imminoglobine against those specific clostrodiume organisms in the collastrodiume, providing same increased resistanse against 
the disease in the calf (senger et al., 2004).

1.7.5. Bloat

Abomasal or ruminal bloat is an abnormal accumulation of gas in calf stomach. This is usually caused by abnormal fermentation of milk when the calf is allowed to drink large quantity interval. However other cause of bloat also exists if bloating is sever; the pressure can interfere with the calf ability to breath, resulting to death. Treatment should be initiated immediately to release using stomach tube ,trocure or large needle .The dite and feeding management should be evaluated to prevented the condition (Majak etal.,2008).

\subsection{Status of Calf health problem in Ethiopia}

The information on calf morbidity and mortality in Ethiopia is scarce. Those available are mostly from research and institutional herds, which do not properly represent the predominant smallholder production system existing in the country (Wudu, 2004).

\section{MATERIALS AND METHODS}

\subsection{Study area}

Wolyita Sodo town is found part of Sodo wereda in Wolayta zone and located at about 390 kilometres sout hwest to Addis Ababa. The wereda has three different agro-ecological zones; $6.13 \%$ highland, $87.7 \%$ midland and $8.4 \%$ is lowland. The altitude range of the area is 1200 to 2950 m.a.s.l. (top of mount Damota). The area receives total annual rainfall of $1112.3 \mathrm{~mm}$ and theannual average maximum temperature of $25.0^{0} \mathrm{c}$ and annual average minimum temperature of $14.5^{\circ} \mathrm{c}$. The wereda has $94,746,17,405,4761$, and 2, 993 cattle, sheep, goats and equines respectively (CSA, 2001).

\subsection{Study Population}

The sampling units for the clinical examination the study on calf were smallholder dairy calves. All calves from dairy farms in Wilayita Sodo and its surrounding constituted the study population. There were different dairy farms with different herd size.

For questionnaire survey the study population were dairy farmers was sampled from small scale dairy owners found in and around Wolyita Sodo town.

\subsection{Study Design}

Purposive sampling method was employed to select study farms that have got individual dairy calf history or able to recall history of their farm at least the last calving and willing to be part of the study. Finally 70 smallholder dairy farm owners information was considered as dependable and used for the study. So 141 calves found reared under the above mentioned farms were also used for clinical examination.

2.3.1. Questionnaire survey

A cross-sectional survey was carried out across the farms a well structured questionnaire was administered to the 70 dairy farmers by one visit interview. The questionnaire was designed to collect information on farm characteristics, calf management techniques including per parturient care, feeding and housing, and previous history of calf diseases. The sample of questionnaire format is shown in Annex 1, together with this study observational study on management (housing), feeding and calf health were recorded.

2.3.2. Clinical examination of calves

Calves were examined by clinical conditions and were diagnosed based on presenting clinical signs in the actual calf examination work, calves were examined visited only once.

The main activities accomplished during examination were:

- Clinical examination of calves for any health problem. This involved physical examination of calves and taking normal body parameters like body temperature, respiratory rate and pulse rate when abnormality was suspected

- Observation on different calf management aspects like cleanness of the calf house and feeding practices

- Asking the owner or the calf attendants the occurrence of calf health problem incidents during the visits and recording of the history of the calf health problem that would enable the investigation to infer the possible cause and thus assist diagnosis. In addition the age, sex, breeds and body condition of each individual calf was recorded.

- Finally tentative diagnosis was reached based on the clinical finding after thorough examination.

\subsection{Data analysis}

A descriptive account of the state of nature of smallholder production systems was statistically described by means and standard deviations, and frequency distributions of the variables. Where appropriate, epidemiological indices. 


\section{RESULTS}

\subsection{Questioners survey results}

\subsubsection{Household data}

Major house and farm characteristics of the respondents are shown in tables 1.

This study revealed house heads age range of the small scale dairy owners was between 27-70 years, with an overall median age of 40.8 years. The 70 smallholder dairy farmers owners involved in the study were having diverse educational statuses (Table, 1) and $47.15 \%$ of the smallholder farms were owned by women. The majority of the households (63.9\%) had 6-10 persons Table 1 House Hold Data Chrematistics of Dairy Farm Owners

\begin{tabular}{lll}
\hline Parameter & Frequency & Percentage \\
\hline Age of respondent & 55 & 78.57 \\
$30-45$ & 12 & 17.14 \\
$46-60$ & 3 & 4.29 \\
$\geq 61$ & 37 & \\
\hline Dairy farm owners gender & 33 & 52.85 \\
Male & & 47.15 \\
Female & 38 & \\
\hline Respondents Education & 15 & 54.28 \\
Elementary & 11 & 21.42 \\
Junior high school & 6 & 15.71 \\
Diploma & & 8.59 \\
University &
\end{tabular}

Number of house hold members

$\begin{array}{lll}1-5 & 5 & 13.9 \\ 6-10 & 23 & 63.9 \\ \geq 11 & 8 & 22.2\end{array}$

Duration of the farm(years)

$\begin{array}{lll}2-5 & 9 & 12.8 \\ 6-9 & 23 & 32.8 \\ & & 54.4\end{array}$

$\geq 10$

The study also revealed that out of the 70 dairy animal owners interviewed 34(48.6\%) of them were dependent on dairy farms as their main income together with other incomes such as other business, salary and others. More over $17.1 \%(12 / 70)$ of them were totally dependent on the income they generate from their dairy farms.

The respondents were asked how they started dairy farm, 51.4\%(36/70) witnessed that they bought the animals by their own money, where as $15.7 \%(11 / 70)$ them had taken loan either from a bank or friends to establish their dairy farms, and the remaining $8(11.4 \%)$ and $15(21.4 \%)$ of the interviewees responded that they started raring dairy cattle as they got it through inheritance form their parents and other means respectively. It was also revealed that $54.4 \%$ and $32.8 \%$ of the respondent had more than ten and five years of dairy farming experience respectively.

3.1.2. Calf management practice (housing and feeding)

Assessment of the type of dairy house in the study area revealed that $17.1 \%$ of them use no shed or any kind of construction to keep their animals (open), and $57.1 \%$ of them were found to use a shed to keep their animal (Table 2). In relation with calves $78.6 \%$ of the owners kept their calves in the same shed as adult animals, more over calving is exercised in the same barn where other animals kept in $90 \%$ of the cases (Table 2). Generally the dairy farms were poorly constructed with no concrete floors.

However, farmers indicated a rather high degree $(77.1 \%)$ of awareness about colostrum in managing newborn calves, $55.7 \%$ of owners indicated that feeding of first colostrum was within six hours after birth, but $15.7 \%$ of the owners do not know the appropriate time when to the new born should get colostrum. In addition $97.2 \%$ of the owners in this survey did not make any care on the navel of new born (Table 2)

Most dairy calves are supplemented with seasonal crop residues and by-products. Some of the major forage species fed to dairy animals were: hay, grassy, by product of 'tella' (atella), concentrate such as oil seed cake (not in the majority of the cases). According to the majority of the owners $(75.7 \%)$ start providing supplement feeds to their calves when they reach in age group of 3.1- 4.5 months (Table 2). According to the result of this survey the average age at weaning was found to be $4.8 \pm 1$ months, with minimum of two months and maximum 
of six months age at weaning.

Table 2. Some variables inspected or measured at the farm or animal level (calves)

\begin{tabular}{lll}
\hline Variables & $\begin{array}{l}\text { Number of } \\
\text { Farms exercising }\end{array}$ & Percentage \\
\hline Calf Housing & 7 & 10 \\
Solid & 40 & 57.1 \\
Only shed & 12 & 17.1 \\
Open & 11 & 15.8 \\
Shed and open & & \\
\hline Calving place & 7 & 10 \\
Calving pen & 63 & 90 \\
Same Barn & & \\
\hline Calf keeping place & 15 & 21.4 \\
Separate calf pen & 55 & 78.6 \\
Live with the other together & & 2.8 \\
\hline Navel care & 2 & 97.2 \\
Yes & 68 & \\
No & & 77.1 \\
\hline Awareness about & & 22.9 \\
Importance of colostrum & 54 & 55.7 \\
Yes & 16 & 28.6 \\
No & & 15.7 \\
\hline First time of colostrum feeding after birth & 39 & 18.6 \\
In 6hrs & 20 & 75.7 \\
$6-24$ hrs & 11 & 5.7 \\
No idea & & \\
\hline Time to start other feed (month) & 13 & \\
$2-3$ & 53 & \\
$3.1-4.5$ & & \\
$>4.5$ & & \\
\hline 3.1 .3$. Expence & & \\
\hline
\end{tabular}

3.1.3. Experience on calf health problems

Table summaries some of the major health problems reported by the owners during. The majority of the problems as it was reported by the owners were associated with gastrointestinal abnormalities (58. 6\%), followed by still birth (18.7\%), inappetance (17.1\%) and respiratory problem, such as coughing (15.7\%).

$52 . \%(37 / 70)$ of the respondents observed calf mortality in their farms, and the total number of calves died in last year in the survey dairy small holder was 82 .

Table 3 Some major calf health problems recorded on smallholder dairy farms in and around Wolaita Sodo town.

\begin{tabular}{lcc}
\hline Health problems & $\begin{array}{c}\text { Number of respondents reported } \\
\text { the case }\end{array}$ & $\begin{array}{c}\text { Percentage } \\
(\%)\end{array}$ \\
\hline 1.Gastrointestinal disorders & 41 & 58.6 \\
1.1. Abdominal distension & 27 & 38.6 \\
1.2.Constipation & 6 & 8.6 \\
1.3.Diarrhoea & 8 & 11.4 \\
2. Respiratory disorder (Coughing, nasal & 11 & 17.1 \\
discharge etc...) & & 7.1 \\
3.External and internal parasites & 5 & 10 \\
4. Loss of weight & 7 & 18.6 \\
5.Still birth & 13 & 8.6 \\
6. Sudden death & 6 & 14.3 \\
7. Un defined health problems & 10 & 52.8 \\
8. Occurrence of mortality & & \\
$\quad$ Yes & 37 & \\
\hline
\end{tabular}

\subsection{Prevalence of Health problems Based on clinical examination}

Physical examination was done on 141 calves reared under the 70 dairy farms owners involved in the interview during the study period for any observable clinical signs of abnormality (diseases). The analysis these results indicated that $44(31.21 \%)$ of the examined calves were had at least one health problem (morbidity), and Significant variation $\left(\mathrm{P}<0.05, \mathrm{DF}=2, \chi^{2}=9.06\right)$ was observed the overall health problem occurrence among 
the three categories of body conditions (Table 3 ).

Table 4 The overall health problem prevalence in different sex, age, body condition and breed of caves examined

\begin{tabular}{|c|c|c|c|c|}
\hline Variables & $\begin{array}{l}\text { Number } \\
\text { examined }\end{array}$ & $\begin{array}{l}\text { Number of calvs showed clinical sign } \\
\text { (Prevalence) }\end{array}$ & $\chi^{2}$ & P-value \\
\hline \multicolumn{5}{|l|}{ Sex } \\
\hline Female & 64 & $21(32.8)$ & 0.15 & 0.70 \\
\hline Male & 77 & $23(29.8)$ & & \\
\hline \multicolumn{5}{|l|}{ Age (month) } \\
\hline $2-3$ & 67 & $22(32.8)$ & & \\
\hline 4 & 33 & $8(24.2)$ & 3.87 & 0.28 \\
\hline 5 & 19 & $9(47.4)$ & & \\
\hline 6 & 22 & $5(22.7)$ & & \\
\hline \multicolumn{5}{|c|}{ Body condition } \\
\hline Good & 83 & $13(15.7)$ & 9.68 & 0.008 \\
\hline Medium & 34 & $9(26.5)$ & & \\
\hline Poor & 24 & $11(45.8)$ & & \\
\hline \multicolumn{5}{|c|}{ Breed of calves } \\
\hline Cross breeds & 8 & $4(50)$ & & \\
\hline Holstein & 75 & $11(14.6)$ & 4.96 & 0.174 \\
\hline Jersey & 36 & $15(41.6)$ & & \\
\hline Local & 22 & $7(31.8)$ & & \\
\hline
\end{tabular}

The sex, age, breed of the calves examined were not found to influence the health problems observed (P < $0.05)$ (table 4).

The major diseases or conditions recorded in the examined calves were respiratory problem (pneumonia, coughing, nasal discharges), diarrhoea, poor body conditions in $13.48 \%, 12.77 \%$ and $17.02 \%$ of the calves examined (Table 5).

Table 5 Health problems observed on clinical examination $(n=141)$

\begin{tabular}{lcc}
\hline Health problems/conditions & Number of calves with the problem & $\begin{array}{l}\text { Percentage } \\
\text { (prevalence) }\end{array}$ \\
\hline Diarrhoea & 18 & 12.77 \\
Depression & 4 & 2.84 \\
Abdominal & 1 & 0.7 \\
distension & & \\
Eye infection & 13 & 9.22 \\
Pneumonia & 19 & 13.48 \\
\hline Body condition & & \\
Good & 83 & 58.8 \\
Medium & 34 & 24.18 \\
Poor & 24 & 17.02 \\
\hline
\end{tabular}

\section{DISCUSSION}

Involvement of women in dairy farming (owners) in the study area was found to be very high (47.15\%), when compared to the previous reports of $38 \%$ and $11 \%$ women ownership of small dairy farms of Debreziet and Jimma by Mekonnen et al, 2006 and Cherenet (2009) respectively. This indicates that smallholder dairy farming provides self-employment to women and, therefore, contributes to the alleviation of poverty in this particular group. A reason for this could be the results of women supportive by current local government and previous nongovernmental organizations (NGOs) which have increased support to rural women in agriculture since the 1967s (the Wolaita Agricultural Development Unit (WADU). The majority (54.4\%) of the dairy farm owners in the present study have started, this condition could again be associated with the above mentioned facts.

The study also revealed that out of the 70 dairy animal owners interviewed $34(48.6 \%)$ of them were dependent on dairy farms as their main income, this indicates that smallholder dairy is becoming an attractive business in a growing towns like Wolyita Sodo.

Animal sheds are in general poorly constructed. Moreover, most owners paid little attention to the importance of having properly constructed calf sheds; in addition the majority of the calves were kept with other adult animals. Thus, these situations cloud put calves easily prone to pneumonia, diarrhoea, parasitic diseases, mortality, kicking and trampling by mature animals as it is reported elsewhere ( Kivaria et al., 2006; Mekonnen et al.,2006; Wudu et al., 2008).

The survey revealed that the majority $(77.1 \%)$ of the farmers do have awareness about colostrum, but $15 \%$ of the dairy owners do don't know about the right time to feed to calves. In this study $55.7 \%$ of the owners 
practiced feeding of colostrum to the new born with 1-6hrs after birth. This was considered by different researchers as a good practice of ensuring enough milk to the calves in the early days to keep the animals health and protect liability to some neonatal diseases and mortality.(Besser et al, 1991; Gay et al., 1988). Contrary to the above groups of owners, more than $28 \%$ of the interviewed dairy farm owners were allowing the new born calves to suckle either after $6 \mathrm{hr}$ or don't know the right time to feed colostrum to their calves. In relation with the delayed first colostrum feeding (later than 6 hours of age), some authors reported a higher risk of mortality in weaned calves (Matte et al. 1982; Bath et al. 1985 le Rousie et al. 2000; Wudu et al, 2008).

The average weaing age (4.8 month) observed in the current study higher than the reports of Wudu et al, 2008 in Ethiopia and comparable with similar small scale dairy surveys done in Tanzania (Jelly et al, 2010) and Zimbabwe (Kaziboni et al, 2004), these authors recorded weaning ages of 3-8 and 4-6 months. Radostits (2001) suggested that calves should be weaned only when they are capable of thriving on a non milk feed.

The main health problems observed during the clinical examination and according to the farm owners preconceptions were gastrointestinal abnormalities (in 58. 6\% of the examined calves) more importantly abdominal distension, diarrhoea (11.4\% up on clinical; examination), and constipation. This agrees with the findings Wudu et al. (2008) and Lema et al. (2001) from the central part of Ethiopia of Gitau et al. (1994. Calf diarrhoea is a common, complex and multi-factorial disease that is affected by the intrinsic characteristics of the calf, its nutritional and immunological status, the management of the herd, the environment, and various infectious agents (Bendali and others 1999a).

Respiratory system infection was reported by $17.1 \%$ of the respondents and it prevalence among the examined calves ( $\mathrm{n}=141)$ was $13.48 \%$. These findings are in agreement with reports of Lemma et al. (2001) and Hussein (1998) in Ethiopia and many other studies elsewhere, which reported pneumonia as the second important disease complexes that affect calf health (Olsson et al., 1993; Debanth et al., 1995; Sivula et al., 1996; Wudu et al, 2008).

The other health problem reported by the dairy owners was still birth (premature birth), where $18.6 \%$ of them witnessed observing the case in their farm in the last two years before this study was undertaken. Such kind of problem was not reported in pervious similar studies in Ethiopia. Factor(s) involved were not inquired but a further detailed study is needed in the area. However the finding was in agreement with a similar questionnaire survey done in Turkey by Erdogan et al (2009), who reported premature birth of up to $20 \%$ in some dairy farms of Kar district. In addition studies under improved farming system in the developed countries suggested that abortion, still birth and congenital defects account for approximately $2 \%$ to $3 \%$ of calf mortality and include the common causes of such problems could be brucellosis, leptospirosis, intrapartum hypoxia, inherited and non inherited congenital defects (Judson and Radostits, 2001).

A variety of host related risk factors were tested for their association(table) with overall presence or absence of at least one health problem (morbidity) among the 141 examined calves that were found in smallholder farms of Wolayita Sodo. Body condition was the important calf (host) factor found to affect morbidity. It was the only risk factor significantly associated with risk of morbidity $\left(x^{2}=9.68, D F=2, P\right.$ $=0.008$ ). The risk of morbidity was found to be high in calves with poor body condition.

Age, breed, sex of the examined animals were found to have no influence in the prevalence of morbidity in the current study. However other similar studies done in the country and elsewhere found a different results, for example: Wudu et al (2008), reported that younger calves under three months of age were at higher risk of morbidity and mortality as compared to older calves. Olsson et al. (1993) reported that $65 \%$ and $75 \%$ of morbidity and mortality in three months of life occurred in the first month of age. Waltner-Toews et al. (1986a) also found that $60 \%$ of all deaths occurred in the first months of life over a period of four months. Virtala et al. (1996b) in their three months study showed the peak occurrence of crude mortality and diarrhea at the second week of life, which decreased sharply thereafter.

\section{CONCLUSION AND RECOMMENDATIONS}

The results of the questionnaire and observation of the dairy farms showed that calf management problems such as poor housing, keeping calves with adult, absence of calving pen were prevalent, further more even if there owners do have a high awareness about the importance of colostrum, some of the owners were found to have little knowledge about the right time to feed colostrum to their calves. Providing supplement feed other than milk was well practiced.

The present study also depicted that one third of the calves were affected by at least with one disease condition. Calf gastrointestinal problems, particularly diarrhoea, Pneumonia, still birth were the most predominant health problems identified by the questionnaire survey and clinical examination of calves. The host factors such as sex, breed, and age were found to have no influence on the prevalence of the health problems in the study period.

Based on the above conclusion remarks the following points are important to be considered for the future improvement of calve health in the study area. 
- Advice to the dairy owners should give emphasis to the time of colostrum feeding, proper timing, management of calves (hygiene of barn)

- Maintain proper housing and feeding for calves to reduce diseases

- It is important to identify the causative agents (infectious, non-infectious, nutritional or genetic) involved in the major health problems identified in this study

\section{REFERENCES}

VitalaVirtala, A.M., Mechor, G.D., Grohn, Y.Y., Erb, H.N., Dubovi, E.J. (1996a): Epidemiologic and pathologic characterstics of respiratory tract disease in dairy heifers during the first three months of life. $J$ Am Vet Res 208, 2035 - 2042.

West, G. (1995), Blacks Veterinary Dictionary, 18thed. London: Black publisher Ltd

Abraham, G., Roeder, D.T., Roman, Z. (1992): Agents associated with neonatal diarrhea in Ethiopian dairy Calves. Tropical Animal Health and Production 25, 239-248

Acres, S.D. (1985): Enterotoxigenic Escherichia Coli infection in newborn calves: A review.J Dairy Sci 68, 229 $-256$.

Agerholm, J. S., Bessa A., Krogh, H. V., Christene, K., Ronshoit, L. (1993): Abortion and calf mortality in Danish cattle herds. Acta vet. scand. 34, 371-378.

Aiello, S.E. (1998): The Merck Veterinary Manual. 8thed. New Jersy: Merck \& Co. Inc.

Aldridge, B., Garry, F., Adams, R. (1992): Role of colostral transfer in neonatal calf management: failure of acquisition of passive immunity. Compendium Continuing Education for Practicing Veterinarian 14, 265269.

Amoki, O.T. (2001): Management of dairy calves in Holleta area, central highlands of Ethiopia. Faculty of veterinary medicine, Addis Ababa University, Debre Zeit, Ethiopia, MSc ,thesis

Bakheit, H.A. (1981): Control of bovine neonatal diarrhea by management technique.Veterinary Record 108, $455-458$

Barger, IA. 1999. The role of epidemiological knowledge and grazing management for helminth control in small ruminants. International Journal of Parasitology 29:41-47.

Bath, D.L., Dickinson, F.R., Tucker, H.A., Appleman, R.D. (1985): Dairy Cattle: Problems, Practices, Problems and Profits, $3^{\text {rd }}$ ed. Philadelphia: Lea and Febiger. PP 325-338.

Belihu, K. (2002): Analysis of dairy cattle breeding program in selected areas of Ethiopia. Landwirtsch AftlichGartenerische Fakultat der Humbodt Universitat Zu Berlin, joPhD.Thesis.

Bendali, F., Bichet, H., Schelcher, F., Sanna, M. (1999a): Pattern of diarrhea in newborn calves in south- west France. Veterinary research 30, $61-74$ (abstract).

Besser, T.E., Gay, C.C., Pritchett, L. (1991): Comparison of three methods of feeding colostrum to dairy calves. $J$ Am Vet Med Assoc 198, 419-422.

Bringntole, J.B. and Stott, G.M. (1980): Effect of suckling followed by feeding colostrum in immunoglobulin absorption and calf survival. $J$ Dairy Sci $\mathbf{6 3}, 451-456$.

Britney, J.B., Martin, S.W., Stone, J.B., Curtis, R.A. (1984): Analysis of early calfhood health status and subsequent dairy herd survivorship and productivity. Preventive Veterinary Medicine 3, 45-52.

-Bruning-Fann, C. and Kaneene, J.B. (1992): Environmental and managemental risk factors associated with morbidity and mortality in perinatal and preweaning calves: a review from an epidemiological perspective. Veterinary Bulletin 62, 399-403.

Busato, A., Steiner, L., Martin, S.W., Shoukri, M.M., Gaillard, C. (1997): Calf health in cow calf herds in Switzerland. Preventive Veterinary Medicine 30, 9-22.

C S A (2001): Central Statistical Authority, Federal Democratic Republic of Ethiopia, central statistical investigatory, Statistical abstract, 2001.

Cry, W.C.J., Casey, T.A., Bosworth, B.T., Rasmussen, M. A. (1998): Effect of dietary stress on fecal shedding of E. coli O157:H7 in calves. Applied Environmental Microbiology 64, 1975-1979. (abstract)

Cunningham, J.G. (1992): Text Book of Veterinary Physiology. Philadelphia: W. B Sounders Company. Pp331.

Debnath, N.C., Taimur, M.J., Gburr, E.C. (1995): A retrospective study of calf losses on the central dairy cattle breeding station in Bangladish. Preventive Veterinary Medicine 24,43 - 53.

Donovan GA, Dohoo IR, Montgomery DM, Bennett FL:(1998) Calf and disease factors affecting growth in female Holstein calves in Florida, USA. Prev Vet Med, 33:1-10.

Drewry, J.J., Quigley, J.D., Geiser, D.R., Matthew, G.W. (1999): Effect of immunoglobulin G absorption in calves. Am J Vet Res 60, 609-614.

Edwards, S.A., Broom, D.M., Collins, S.C. (1982): Factors affecting level of passive immunity in dairy calves. British Veterinary Journal 138, 223 - 240.

Erdoğan M, Kostova Z, Marcinkowski T (2009). Components of environmental literacy in elementary science education curriculum in Bulgaria and Turkey. Eurasia J. Math. Sci. Techn. Educ., 5(1): 15-26. 
Garber ,L.P., Salman, M.D., Hurd, H.S., Keefe, T., Schlater, J.L. (1994): Potential risk factors for Cryptosporidium infection in dairy calves. J Am Vet Med Assoc 205, 86 -90.

Garry, F., Aldeidge, B., F., Adams, R. (1993): Role of colostral transfer in neonatal calf management: current concepts in diagnosis. Compendium Continuing Education for Practicing Veterinarian 15, 1167-1174.

Gay, C.C., McGuire, T.C., Parish, S. M. (1983): Seasonal variation in passive transfer of IgG1 to newborn calves. $J$ Am Vet Med Assoc 183, 566-568.

Gay, N., J.A. Boling, R. Dew, and E.D. Miksch. 1988. Effects of endophyte-infected tall fescue on beef cow-calf performance. Appl. Agric. Res. 3:182.

Gitau, G.K., McDermott, J.J., Waltner-Toew, D., Lissemore, K. D., Osuma, J.M., Muriuki, D. (1994): Factors Influencing calf morbidity and mortality in smallholder dairy farms in Kambu district of Kenya. Preventive Veterinary Medicine 21, 167-177.

Gitau, G.K., Perry, B.D., McDermott, J.J., 1999. The incidence, calf morbidity and mortality due to Theileria parva infections in smallholder dairy farms in Murang'a district, Kenya. Prev. Vet. Med. 39, $65 \pm 79$.

Gryeels, G. and de Boodet, K. (1986): Integration of Crossbred cows (Boran and Freisian) on smallholder farms in Debre Zeit area of the Ethiopian highlands. ILCA highland program report. ILCA, Addis Ababa.

Hailemariam, M., Banjaw, K., Gebre Meskel, T., Ketema, H. (1993b): Productivity of Boran cattle and their Friesian cross at Abernosa ranch, Riftvalley of Ethiopan. I. Reproductive performance and preweaning mortality. Tropical Animal Health and Production 25, 239-248

Hailemariam, M., Mekonnen, G., Beker, A. (1993a): Preweaning performance of Fogera calves and their Friesian crosses in North- western Ethiopia. World Review of Animal Production 28, 61-66.

Hailu Degefu, Cherenet Abera, Moti Yohannes and Tadele Tolosa(2011): Gastrointestinal Helminth Infections in Small-scale Dairy Cattle Farms of Jimma Town, Ethiopia

Hancock, D.D. (1985): Assessing efficiency of passive immune transfer in dairy herds. J Dairy sci 68, 163-183.

Heinrichs, A.J. and Radostits, O..M. (2001): Health and production management of dairy calves and replacement heifers. In: Radostits, O.M. (ed.): Herd Health, Food Animal Production Medicine, $3^{\text {rd }}$ ed. Philadelphia, W.B. Saunders Company. Pp, $333-395$

Hill,T.M., Alderch,J.M., Scholtterbeck, R.L. and Betman H.G.(2007): Amino acid ,fatty acid and source for calve milk replacer .pro.Anim.sci.23:401-408.

Hunt, E. (1993): Diarrheal disease of neonatal ruminants. In: Howard, J.L. (ed.): Current Veterinary Therapy, Food Animal Practice. 3rd ed. Philadelphia W.B Sounders Company Pp, 103- 111.

Hussien, N. (1998): A study on calf mortality at Adamitulu livestock research center.Proceeding of 5th conference of Ethiopian society of animal science (ESAP) 15-17 May 1997, Addis Ababa, Ethiopia. Pp $157-162$

ILCA annual program report 1993/1994 Addis Ababa, Ethiopia. PP 73-74.

ILRI (1996): ILRI annual project report 1995, Addis Ababa, Ethiopia.Pp74 -75

Kasari, R.T. (1993): Omphalitis and its sequelae in ruminants. In: Howard, J.L. (ed.): Current Veterinary Therapy, Food Animal Practice. 3rd ed. Philadelphia: W.B Sounders Company. Pp $101-103$.

Kassai, T. 1999. Veterinary Helminthology. Butter Worth-Heine-mann. Linacre House.Jordan Hill, Oxford, 225 wildwood Avenue. pp. 260.

Kassai, T. 1999. Veterinary Helminthology. Butter Worth-Heine-mann. Linacre House.Jordan Hill, Oxford, 225 wildwood Avenue. pp. 260.

Kazibonis.,kusina N.T,sibanda S.,Nyonio and Bhabha(2004) Performansi artifitial in simination in smoll holder of Nharia-lancasher in Zimbabwe animal scince department ,university of pleasant,Harare,zembabew.

Kivaria F M, Noordhuizenm J P T M and Msami H M 2006 Risk factors associated with the incidence rate of clinical mastitis in smallholder dairy cows in Dar es Salaam region of Tanzania. The Veterinary Journal 173(3): 623-9

Komine, Y., Abe, S., Asai, A., Itagak, M., Wantanbe, D., Komine, K., Kumagai, K. (2000): Induction of infectious diarrhea in newborn calves fed dysplasia colostrum of mother cows suffering from mastitis during dry period. Animal Science Journal 71, 279-285.

Lance, S.E., Miller, G.Y., Hancock, D.D., Bartlet, P.C., Heider, L.E., Moeschberger, M.L. (1992a): Effects of environment and management on mortality in preweaned dairy calves. J Am Vet Med Assoc 201, 1197-1202.

Lemma, M., Kassa, T., Tegegne, T. (2001): Clinically manifested major health problems of crossbred dairy herds in urban and periurban production systems in the central highlands of Ethiopia. Tropical Animal Health and Production 33, 85-93

Loyacano,A,F,Willames,j,Gurie,J.,Deross,A.A.,2002.Effect of gastrointestinal namatod and liver fluke infectionon weigt gain and reproductive performance of beef heifervet,parstol,107,227-234.

Lyimo,H.L.N.,Metenga,L.A.,Kimambo,A.E.,Hvelplund T.,Laswai G.H and Weisebirg ,M.R,(2004) Survey on calf feeding system ,problem and improvement option available for smoll holder dairy farmer of Tarunin in Tanizania ,livestooke reaserch for rural development ,16(23):1-8. 
-Mainge,E.N.,(1996):Atihelmentic resistance ,epidimology and controle of gastrointestinal nematode in neyandaru distinct of Kenya and in Denmark,Ph.D,thesis ,university of Nirobi.sci.8,215.

Majak,W., Garland,G.J., Laysak,t.j. (2008):the effect of feeding hey before fresh alfalfa on the ocuranse of the froth bloat in cattle .can,J.Anim,scin.88:1-3.

Marsden,P,D, and Werren ,k.s.,(1984): Fascioloses in tropical and geographical medicine (ed,k,s,waren and A.A.F.mahamud )pp.485-60Mc Graw hill,new York.

Matte, J. J., C. L. Girard, J. R. Seoane, and G. J. Brisson. 1982. Absorption colostral immunoglobulin G in the newborn dairy calf. J. Dairy Sci. 65: 1765-1770.

McDonough, S. P., Stull, C.L., Osburn, B.I. (1994): Enteric pathogens in intensively reared veal calves. Am J Vet Res 55, $1516-1520$.

Mekonnen H M, Asmamaw K and Courreau J F 2006 Husbandry practices and health in smallholder dairy farms near Addis Ababa, Ethiopia, Preventive Veterinary Medicine, 74: 99-107.

Menge,c.,Bourgen H.,Toulline,J.,Rondeland ,D.,Drefuse,G.,2002,Fasciola hepatica and paraphistome debaniy:change in privalense of natural infection in cattle and lyminaca trancatula froma canteral France over the past 12 years vet Ress,33,439-447

Mohammed, H.O., Wade, S.E., Schaaf, S. (1999): Risk factors associated with Cryptosporidium parvum infection in dairy cattle in Southeastern New York State. Veterinary Parasitology 83, 1-13.

Murphy, F.A., Gibbs, P.J., Hurinek, M.C., Studdert, M.J. (1999): Veterinary Virology, 3rded. Sandiago: Academic press.

Nansen,p.,Foldager,J,W.,Henerksen,S,A.,Jergensen.R,J.,1988.Grezing pressure and acquisition of O,ostrtage in calve ,vet,parstol,27,325-335.

Nin-Pratt A and X. Diao. 2006. Exploring growth linkages and market opportunities for agriculture in southern Africa", DSGD Discussion Paper No.42, International Food Policy Research Institute (IFPRI), Washington DC.

Olsson, S.O.,Viring, S., Emanuelsson, U., Jacobsson, S.O. (1993): Calf disease and mortalityin Swedish dairy herds. Acta. vet. scand. 34, 263-269.

-Ongerth, J.E. and Stibbs, H.H. (1989): Prevalence of Cryptosporidium infection in dairy calves in western Washington. Am J Vet Res 50, 1069 - 1073.

Quilez, J., Sanche-Acido, C., delCacho,E., Clavel, A. (1996): Prevalence of Cryptosporidium and Giardia infections in cattle in Aragon (N.E. Spain). Veterinary parasitology 66, 139 - 146.

Rebhun, W.C., Guard, C., Richards, C.M. (1995): Disease of Dairy Cattle. USA: William and Wilkins. PP 155175.

Reynolds, G.C., Morgan, T.G., Chanter, N., Jones, P.W., Bridger, J.C., Debency, T.G., Bunch, K.J. (1986): Microbiology of calf diarrhea in Southern Britain. Veterinary Record 119, 34-39.

Rodiostiti, O, M., Blood, D.C., and Gay, C.C., (1994): atext book of the disease of the cattle ,sheep, pig, goat and horse, $8^{\text {th }}$ ed .Bailer Tindall,lendone,563-613.

Rouse, R. J., C. A. McClug, and A. MacNab. 2000. Growing Pumpkin. MD Coop. Ext. Fact Sheet 454.

Runnels, P.L., Moon, H.W., Mattew, P.J.(1986): effect of microbial and hhost variables on the interaction of rotavirus and E. coli infections in genetobiotic calves, Am J Vet Res 47, 1542-1546.

Senger, J. Glenn and Dale,(2004): clostrodiume prefringes type G Entritis in calve: two case and brief review of the literature ,Anarobise 10:239-242.

Sivula, N. J., Ames, T. R., Marshal, W. E. and Werdin, R. E. (1996): Descriptive epidemiology of morbidity and mortality in Minnesota dairy heifer calves. Preventive Veterinary Medicine, 27: 155-177.

Sivula, N.J., Ames, T.R., Marsh, W.E., Werdin, R.E. (1996a): Descriptive epidemiology of morbidity and mortality in Minnesota dairy heifers calves. Preventive Veterinary Medicine 27, 155 - 171.

Snodgrass, D.R., Terzolo, H.R., Sherwood, D., Cambell, I., Menzies, J.D., Synge, B.A. (1986): Etiology of dairrhea in young calves. Veterinary Record 119, 31-34.

Snodgrass, D.R.,Smith, M.L. Krautis, F.L. (1982): Interaction of rotavirus and ETEC inconventionally reared dairy calves. Veterinary Microbiology 7, $51-56$. SPSS inc.

Szmiid,Adjjide,V.,abrous,M.,Adjiide,C,Cdreyfuse,G.,LOcomple,A.,Cabart,J.,ROndelaud,D.,2000.Privalnse of parphistom doubenyi infection in cattle in centeral France .Vet Parasite,87,133-138.

Tayler, J.W., Steevens, B.J., Hostetler, D.E., Holle, J.H., Denbigh, J.L. (1999): Colostral immunoglobulin concentration in Holiestin and Guernsey Cows. Am J Vet Res 60, 1136- 1140.

Taylor.S.M.,Kennya,J.,Edjigar,H,WMallor T.R.,Canavan.A.,2000 Indaction of protective immunity to Dictocaulose viviporsuse in calve while under tritement with indocytocyedse.vet parstolol, 67,207-228.

Tegegne, A., Gebrewold, A. (1998): Prospects for peri-urban dairy development in Ethiopia. Proceeding of 5th conference of Ethiopian society of animal science (ESAP), 15-17 May 1997, Addis Ababa Ethiopia. Pp 2839.

Tizard, I. (1995): Veterinary Immunology. 4th ed. Philadelphia: W.B. Saunders Company. 
Virtala, A.M., Grohn, Y.T., Erb, H.N. (1999): The effect of maternally derived Ig G on the risk of respiratory disease in heifers during the first three months of life. Preventive Veterinary Medicine 39, 25-37.

Virtala, A.M., Mechor, G.D., Grohn, Y.Y., Erb, H.N. (1996b): Morbidity from nonrespiratory disease and mortality in dairy heifers during the first three months of life. J Am Vet Res 208, 2043 - 2046.

Waltner-Toews, D., Martin, S.W., Merk, A.H. (1986a): Effect of calfhood disease on survivorship and age at first calving. Can J Vet Res 50, 314-317.

Waltner-Toews, D., Martin, S.W., Merk, A.H. (1986c): Dairy calf management, morbidity and mortality in Ontario Holstein herds. II Age and seasonal patterns. Preventive Veterinary Medicine 4, 125-135.

Waltner-Toews, D., Martin, S.W., Merk, A.H. (1986e): Epidemiological study of selected calf pathogens on Holstein dairy farms in southwestern Ontario. Can J Vet Res 50, 307-313.

Warnick VD, Arave $\mathrm{CW}$, Mickelsen $\mathrm{CH}$ : Effects of group, individual and isolated rearing of calves on weight gain and behaviour. J Dairy Sci 1977, 60:947-953.

Webester, J. (1984): Calf Husbandry Health and welfare. London: Granada publishing Ltd. PP 1-17.

Wells, S.J., Dargatz, D.A., Otto, S.L. (1996): Factors associated with mortality to 21 days of life in dairy heifers in United states. Preventive Veterinary Medicine 29, 9-19.

White, D.G., Andrew, A.H. (1986): Adequate concentration of circulatory colostral proteins for market calves. Vetrinary Record 119, 112-114.

Wilson, J.B., Renwick, S.A., Clarke, R.C., Rahan, K., Alves, D., Johnson, R.P., Ellis, A.G, McEwen, S.A., Rarmali, M.A., Lior, H., Spika, J. (1998): Risk factor for infection with verocytotoxigenic Escherichia coli in cattle on Ontario dairy farms. Preventive Veterinary Medicine 32, 227-236.

Wittum T.E. Salmon M.D., king M.E. (1994): Individual animal and maternal beef caves inColordo, USA. Preventive Veterinary Medicine 19, 1 - 14.

Wudu T, Kelay B, Mekonnen HM, Tesfu K. Calf morbidity and mortality in smallholder dairy farms in Ada'a Liben district of Oromia, Ethiopia. Tropical Animal Health and Production. 2008;40:369-376 